\title{
mFISH analysis of chromosome aberrations in workers occupationally exposed to mixed radiation
}

\author{
Natalia V. Sotnik - Sergey V. Osovets • \\ Harry Scherthan - Tamara V. Azizova
}

Received: 5 August 2013/Accepted: 28 February 2014/Published online: 9 April 2014

(C) Springer-Verlag Berlin Heidelberg 2014

\begin{abstract}
We performed a study on the presence of chromosome aberrations in a cohort of plutonium workers of the Mayak production association (PA) with a mean age of $73.3 \pm 7.2$ years to see whether by multi-color fluorescence in situ hybridization ( $\mathrm{mFISH}$ ) translocation analysis can discriminate individuals who underwent occupational exposure with internal and/or external exposure to ionizing radiation 40 years ago. All Mayak PA workers were occupationally exposed to chronic internal alpha-radiation due to incorporated plutonium-239 and/or to external gamma-rays. First, we obtained the translocation yield in control individuals by mFISH to chromosome spreads of age-matched individuals and obtained background values that are similar to previously published values of an international study (Sigurdson et al. in Mutat Res 652:112-121, 2008). Workers who had absorbed a total dose of $>0.5$ Gy external gamma-rays to the red bone marrow (RBM) displayed a significantly higher frequency of stable chromosome aberrations relative to a group of workers exposed to $<0.5$ Gy gamma-rays total absorbed RBM dose. Thus, the translocation frequency may be considered to be a biological marker of external radiation exposure even years after the exposure. In a group of workers who were internally exposed and had incorporated plutonium-239 at a body burden $>1.48 \mathrm{kBq}, \mathrm{mFISH}$ revealed a considerable number of cells with complex chromosomal rearrangements. Linear associations were
\end{abstract}

N. V. Sotnik $(\bowtie) \cdot$ S. V. Osovets · T. V. Azizova Southern Urals Biophysics Institute (SUBI), 19 Ozyorskoe Shosse, Ozyorsk, Chelyabinsk Region 456780, Russia e-mail: sotnik@subi.su

H. Scherthan

Bundeswehr Institute of Radiobiology Affiliated to the University of Ulm, Neuherbergstr. 11, 80937 Munich, Germany observed for translocation yield with the absorbed RBM dose from external gamma-rays as well as for complex chromosomal rearrangements with the plutonium-239 body burden.

Keywords Translocations - Complex aberrations . External gamma-rays $\cdot{ }^{239} \mathrm{Pu}$ body burden $\cdot$ Mixed radiation exposure

\section{Introduction}

The formation of chromosome aberrations has long been considered to be a sensitive biological marker of ionizing radiation (IR)-induced genome damage (Lemos et al. 2010; Iwasaki et al. 2011; IAEA 2011; Pernot et al. 2012). Unstable and stable chromosome aberrations (dicentrics and translocations, respectively) have been established as biological markers of external radiation exposure (Bauchinger et al. 2001; IAEA 2001, 2011; Edwards et al. 2005, 2007; Tucker 2008). However, in vivo studies on the effects of internal alpha-radiation to the human genome are sparse and the data often inconsistent, since the majority of data on aberration induction with alpha emitters stem from in vitro investigations (Brandom et al. 1990; Testard et al. 1997; Anderson et al. 2000, 2003, 2005, 2006; Boei et al. 2001; George et al. 2001; Moquet et al. 2001; Barquinero et al. 2004; Okladnikova et al. 2005, 2009; Tawn and Whitehouse 2005; Hada et al. 2007; Janet et al. 2008; Curwen et al. 2012). Currently, there are no data on the consequences of mixed prolonged occupational exposure with internal and external IR sources with respect to translocation yield and persistence.

Early in vivo studies which performed a routine staining did not reveal an increased chromosome aberration yield in 
workers exposed to internal alpha-radiation (Dolphin 1971; Hempelmann et al. 1973; Voelz et al. 1985), while Brandom et al. $(1979,1990)$ reported an increase in dicentrics, rings, inversions and translocations in Rocky Flats workers after plutonium-239 aerosol inhalation. The authors concluded that the increase in chromosome aberration yield was attributed to internal exposure to plutonium-239 rather than to external gamma-rays. A study on genome instability in Sellafield workers based on a routine Giemsa analysis technique as well as on the fluorescence plus Giemsa staining method showed that the unstable aberration yield in workers exposed to internal alpha-radiation was similar to the unstable aberration yield in control individuals (Whitehouse and Tawn 2001). To the contrary, other studies of Sellafield workers' peripheral blood lymphocytes reported increased frequencies of dicentrics (Schofield 1980) and stable chromosome aberrations (Tawn et al. 1985; Whitehouse et al. 1998). Livingston et al. (2006) revealed an increased chromosome aberration yield in former workers of the Rocky Flats plutonium production facilities compared with controls; the authors of this study showed an association of the translocation yield with the exposure dose for the group of workers with high RBM doses of internal alpha-radiation due to radionuclide incorporation.

Studies of chromosome aberrations in peripheral blood lymphocytes of Mayak PA workers found a pronounced genotoxic effect of plutonium-239 and revealed a correlation between both the total number of aberrations and the number of dicentrics and an absorbed RBM dose from internal alpha-radiation due to incorporated plutonium239 (Okladnikova et al. 2005, 2009). multi-color fluorescence in situ hybridization (mFISH) analysis of chromosome spreads of Mayak PA workers showed that the complex chromosomal rearrangements were significantly increased in plutonium production workers with high plutonium-239 body burdens compared with reactor/plutonium production workers with moderate plutonium-239 body burdens as well as to controls (Hande et al. 2005). Popova et al. (2004) demonstrated that the frequency of cells with multiple chromosome aberrations in workers of Siberian Chemical Industrial Complex with $>13 \mathrm{nCi}$ plutonium-239 body burden was tenfold increased relative to the background frequency. The investigation of various social groups disclosed that cells exhibiting complex aberrations showed the highest yield in workers of a radiochemical facility who had been exposed to mixed radiation (Aseeva et al. 2009).

The present study aimed to assess the spectrum and yield of chromosome aberrations in Mayak PA workers occupationally exposed to mixed radiation using the mFISH assay.

\section{Materials and methods}

The study group consisted of Mayak PA workers who had experienced prolonged occupational external gamma-ray exposure and/or internal alpha-radiation exposure due to incorporated plutonium-239 (Table 1). Chromosome spreads for 60 Mayak PA workers (42 males and 18 females) were analyzed in the present study; the mean age of the study individuals was $73.3 \pm 7.2$ years. $85 \%$ of the study individuals were employed at Mayak PA during the first decade of its operation (1948-1958). $98.3 \%$ of workers were hired prior to the age of 30 years; the mean age of workers as of the beginning of their career at Mayak PA was $23.1 \pm 3.9$ years $(23.2 \pm 4.3$ years in males and $22.8 \pm 2.9$ years in females). Reactor workers who had experienced only external gamma-ray exposures comprised $16 \%$ of the study group. The majority of the study individuals $(84 \%)$ were exposed to mixed radiation. Individual doses from external gamma-radiation according to an updated dosimetry system Doses-2008 (Vasilenko et al. 2007) were used in this study.

Data on plutonium-239 (Pu-239) incorporation were provided by the Department of Internal Dosimetry of the Southern Urals Biophysics Institute. The incorporated

Table 1 Characteristics of the study group (Mayak PA workers)

\begin{tabular}{llll}
\hline & Male & Female & Both \\
\hline $\begin{array}{c}\text { Total dose from } \\
\text { external gamma- } \\
\text { rays to the whole } \\
\text { body } \pm \text { SE, Gy }\end{array}$ & $1.52 \pm 1.15$ & $1.16 \pm 1.01$ & $1.41 \pm 1.12$ \\
$\begin{array}{l}\text { Median (min; max) } \\
\text { Total absorbed dose } \\
\text { from external }\end{array}$ & $0.93 \pm 0.78(0.0 ; 3.95)$ & $0.74(0.09 ; 3.12)$ & $1.40(0 ; 3.95)$ \\
gamma-rays to & & & \\
RBM \pm SE, Gy & & & $0.72 \pm 0.71$ \\
$\begin{array}{l}\text { Median (min; max) } \\
\text { Plutonium-239 body } \\
\text { burden } \pm \text { SE, kBq }\end{array}$ & $1.82 \pm 3.56$ & $4.21 \pm 5.34$ & $2.54 \pm 4.27$ \\
$\begin{array}{l}\text { Median (min; max }) \\
\text { Total absorbed dose } \\
\text { from internal alpha- }\end{array}$ & $0.18(0 ; 14.91)$ & $0.86(0 ; 15.92)$ & $0.32(0 ; 4.52)$ \\
particles to & & $0.18 \pm 0.26$ & $0.10 \pm 0.18$ \\
RBM \pm SE, Gy & & & \\
$\begin{array}{l}\text { Median (min; max) } \\
\text { Period of employment }\end{array}$ & $0.01(0 ; 0.48)$ & $0.03(0 ; 0.84)$ & $0.01(0 ; 0.84)$ \\
$\begin{array}{l}\text { 1947-1953 } \\
\text { 1954-1958 }\end{array}$ & $27(64.3 \%)$ & $16(88.9 \%)$ & $43(71.7 \%)$ \\
post 1958 & $6(14.3 \%)$ & $2(11.1 \%)$ & $8(13.3 \%)$ \\
$\begin{array}{l}\text { Duration of } \\
\text { employment at }\end{array}$ & $9(21.4 \%)$ & $0(0 \%)$ & $9(15 \%)$ \\
Mayak PA, years & $32.3 \pm 13.2$ & $21.2 \pm 11.7$ & $30.0 \pm 13.7$ \\
\hline
\end{tabular}


amount of $\mathrm{Pu}-239$ was estimated by measuring its urine excretion using double phosphate precipitation radiochemistry (Khokhryakov et al. 2000). Doses from the internal exposure to incorporated $\mathrm{Pu}-239$ were estimated from the radionuclide urine data and accounting for its solubility properties, its biodistribution patterns in a human body and the individual's occupational history and smoking status (Khokhryakov et al. 2013). Table 1 shows dosimetric parameters of the investigated Mayak PA workers.

The control group consisted of 15 Ozyorsk residents (8 males and 7 females) who had been constantly living in the city, had not worked with ionizing radiation sources, had never been involved in any cleanup activities following nuclear accidents and had never lived in contaminated regions. The mean age of the control individuals was $62.4 \pm 12.5$ years.

All individuals invited to participate in the study signed a form of informed consent to voluntary participation according to the Russian Federation legislation concerning public health protection. Thereafter, blood samples were obtained from the participants.

Peripheral blood lymphocyte culturing and preparation of chromosome spreads were performed according to a standard protocol. Lymphocytes were pelleted by centrifugation and placed into a culture flask containing $10 \mathrm{ml}$ PB-MAX medium (Gibco). We usually performed culturing of peripheral blood lymphocytes for $48 \mathrm{~h}$ according the international consensus (IAEA 2011). However, because the age of the Mayak PA workers studied here was above 70 years, we sometimes faced poor lymphocyte growth due to advanced donor age. In these cases, the culture conditions were adjusted experimentally (48-72 h) to obtain sufficient metaphase plates. Peripheral blood lymphocyte cultures were supplemented with $5^{\prime}$ bromodeoxyuridine in order to check cell cycle progression during a period of $68-72 \mathrm{~h}$. It was found that most metaphases $(87 \%)$ were in first mitosis, so culturing conditions were adjusted to $68 \mathrm{~h}$ and metaphase cells were enriched by $4 \mathrm{~h}$ colchicine treatment $(0.01 \mu \mathrm{g} / \mathrm{ml})$ before fixation. To this end, cells were first treated with $0.075 \mathrm{M} \mathrm{KCl}$ hypotonic solution for $15 \mathrm{~min}$ at $37{ }^{\circ} \mathrm{C}$, pelleted and fixed with ice-cold mixture of ethanol and glacial acetic acid $(3+1$ parts). The cell suspension was dropped on precooled wet slides and dried in the steam of a hot water bath.

Chromosome aberrations were stained and scored by fluorescence in situ hybridization (FISH) in a multi-color format (mFISH), which allows multi-color staining of all chromosomes in a single metaphase plate. This technique is more reliable and effective than a simple FISH-assay since it allows scoring of aberrations among all chromosomes (e.g., Speicher et al. 1996).

Hybridization of chromosome was performed following the $24 \times$ Cyte lab manual protocol (Metasystems,
Germany). Chromosome spreads were denatured in $0.07 \mathrm{~N}$ $\mathrm{NaOH}$ for $1 \mathrm{~min}$ at a room temperature, while probes were heat denaturated. After combining denatured probes and slides and coverslips, slides were incubated in a moist chamber at $37{ }^{\circ} \mathrm{C}$ for $48-72$ h. Finally, slides were counterstained with DAPI in an antifade solution (MetaSystems, Germany).

Capturing of images of metaphase spreads was performed with an Axio Imager Z.2 fluorescent microscope (Carl Zeiss) equipped with filter sets for DAPI, FITC, Texas Red, Spectrum Orange, DEAC and Cy5 (MetaSystems, Germany). Karyotyping of 100-150 metaphase spreads per individual was done using the ISIS4 software (MetaSystems). An aberration yield per 100 analyzed metaphases was calculated.

Statistics: Correlation and regression analyses were performed using Statistica 6.0 standard package (Borovikov 2003). Student's $t$ test ( $p$ value) and Fisher's $F$ test (Draper and Smith, 1986) were employed to estimate statistical significance of the differences; $p<0.05$ denoted a significant difference.

\section{Results}

In total, we analyzed 10,118 metaphase spreads of our study groups by mFISH. Both stable (translocations, insertions, terminal deletions and complex chromosomal rearrangements) and unstable (dicentrics) chromosome aberrations were observed in the lymphocyte chromosomes of Mayak PA workers, while controls only displayed stable chromosome aberrations (translocations). Aberrations involving three and more breaks in two or more chromosomes were considered complex chromosomal rearrangements (complexes).

The comparison of the chromosome aberration yields of the study groups revealed significantly $(p<0.05)$ increased yields of both stable and unstable chromosome aberrations in Mayak PA workers compared with the chromosome aberration yield of the control individuals (Table 2). Our findings support the observations that the chromosome aberration yield of an exposed population markedly exceeds the corresponding background level

Table 2 Chromosome aberration yield in the study groups

\begin{tabular}{llll}
\hline Group & \multicolumn{3}{l}{ Chromosome aberration yield per 100 cells } \\
\cline { 2 - 4 } & Total & $\begin{array}{l}\text { Stable } \\
\text { aberrations }\end{array}$ & $\begin{array}{l}\text { Unstable } \\
\text { aberrations }\end{array}$ \\
\hline Cases $(n=60)$ & $2.39 \pm 0.26^{*}$ & $4.43 \pm 0.35^{*}$ & $0.36 \pm 0.09^{*}$ \\
Controls $(n=15)$ & $0.67 \pm 0.23$ & $1.22 \pm 0.41$ & $0.13 \pm 0.08$ \\
\hline
\end{tabular}

* Statistically significant difference $(p<0.05)$ to control 
Table 3 Chromosome aberration yield in relation to the absorbed RBM dose from external gamma-rays

\begin{tabular}{llc}
\hline Chromosome aberrations per 100 cells & \multicolumn{2}{l}{$\begin{array}{l}\text { Dose from external gamma- } \\
\text { rays to RBM, Gy }\end{array}$} \\
\cline { 2 - 3 } & $0-0.5$ & $>0.5$ \\
\hline Stable & & \\
All & $3.6 \pm 0.5$ & $5.2 \pm 0.5^{*}$ \\
Translocations & $2.2 \pm 0.5$ & $3.8 \pm 0.4^{*}$ \\
Unstable & $0.4 \pm 0.1$ & $0.3 \pm 0.1$ \\
\hline
\end{tabular}

* Statistically significant differences between the two dose groups $(p<0.05)$

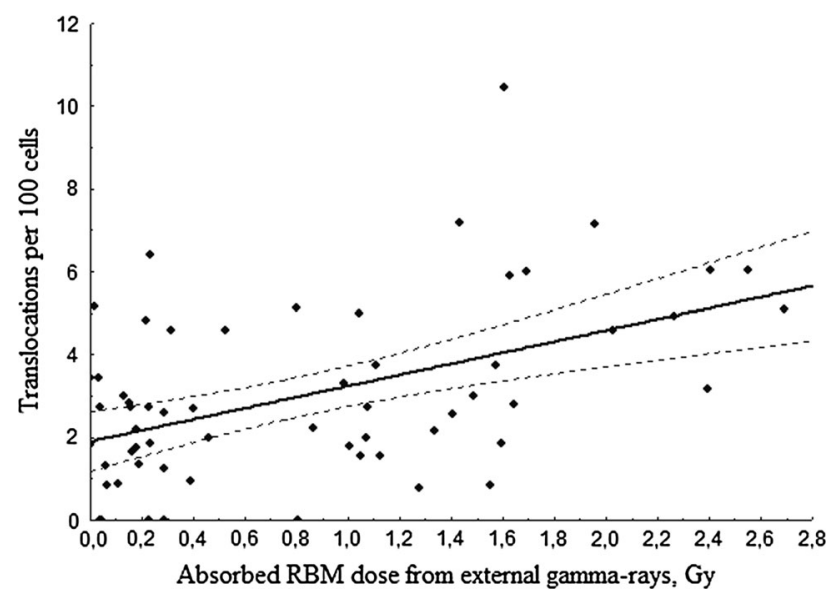

Fig. 1 Translocation yields in relation to the absorbed RBM dose from external gamma-rays. The stippled lines represent $95 \%$ confidence intervals

(UNSCEAR 2000; IAEA 2001, 2011) and may hence be used as a biological marker of chronic radiation exposure, even long after the exposure event.

Table 3 presents the results of the chromosome aberration yield analyses in relation to the total absorbed RBM dose from external gamma-radiation in Mayak PA workers. The yield of stable chromosome aberrations in workers exposed to gamma-rays at total absorbed RBM dose above $0.5 \mathrm{~Gy}$ was significantly higher $(p<0.05)$ than that in workers exposed to gamma-rays at absorbed RBM dose below $0.5 \mathrm{~Gy}$. In the two groups, the majority of stable chromosome aberrations $(87.7 \%)$ were simple translocations. A significant correlation coefficient for the translocation yield and the absorbed RBM dose from external gamma-rays was 0.5 . Figure 1 demonstrates a linear relationship between the translocation yield and the absorbed RBM dose from external gamma-rays, even for exposure events that occurred more than 40 years ago.

Next, we analyzed the spectrum and the yield of chromosome aberrations in Mayak PA workers in relation to $\mathrm{Pu}-239$ body burden. Chromosome aberration yield was
Table 4 Chromosome aberration yield in relation to plutonium-239 body burden

\begin{tabular}{lll}
\hline $\begin{array}{l}\text { Chromosome aberrations per } 100 \\
\text { cells }\end{array}$ & \multicolumn{2}{l}{$\begin{array}{l}\text { Plutonium-239 body burden, } \\
\mathrm{kBq}\end{array}$} \\
\cline { 2 - 3 } & $\begin{array}{l}\text { below } \\
1.48 \mathrm{kBq}\end{array}$ & $\begin{array}{l}\text { above } \\
1.48 \mathrm{kBq}\end{array}$ \\
\hline Stable & & \\
All & $3.96 \pm 0.37$ & $5.57 \pm 0.75^{*}$ \\
Translocations & $2.96 \pm 0.31$ & $3.31 \pm 0.58$ \\
Complex & $0.1 \pm 0.04$ & $0.91 \pm 0.27^{*}$ \\
Unstable & 0 & $0.27 \pm 0.12^{*}$ \\
\hline
\end{tabular}

* Statistically significant differences between the two dose groups $(p<0.05)$

found to be significantly increased in those workers whose $\mathrm{Pu}-239$ body burden exceeded $1.48 \mathrm{kBq}$ compared with workers with less than $1.48 \mathrm{kBq} \mathrm{Pu}-239$ body burden (Table 4). Unstable chromosome aberrations in Mayak PA workers with $\mathrm{Pu}-239$ body burden exceeding $1.48 \mathrm{kBq}$ were found to be dicentrics. All the revealed dicentrics were reported to be constituents of complexes (Fig. 2).

A detailed analysis of the chromosome aberration spectrum revealed that complexes contributed a large portion of registered damages in the group of workers with $>1.48 \mathrm{kBq}$ plutonium-239 body burden. The complex aberration yield $(0.91 \pm 0.27$ per 100 cells $)$ in individuals with more than $1.48 \mathrm{kBq}$ of $\mathrm{Pu}-239$ body burden was significantly higher than that $(0.10 \pm 0.04$ per 100 cells $)$ of workers with less than $1.48 \mathrm{kBq}$ of $\mathrm{Pu}-239$ body burden. The significant correlation coefficient for complexes and Pu-239 body burden was 0.7, while for external gammairradiation there was no significant correlation for this aberration type and the absorbed RBM dose $(r=-0.06)$. For the case of mixed exposures, correlation analysis failed to reveal an association of translocation yield with $\mathrm{Pu}-239$ body burden $(r=-0.09)$, or with the total absorbed RBM dose form internal alpha-particles $(r=0.02)$. Hence, the findings demonstrate that translocations are a biological marker responding to the external gamma-ray exposure when concerning mixed radiation exposures. This may be correlated with a higher RBE and a higher long-term toxicity by alpha emitters (Vandenbulcke et al. 2003) leading to depletion of lethally hit lymphocytes with time.

A sequential regression analysis based on linear and linear-quadratic models revealed that the linear model achieved statistical significance. Lack of significance for just one of the model parameters of the linear-quadratic model rendered the model insignificant. We attribute this fact to a high variability of the data and to a considerable number of null data estimates. Hence, the linear model was the best to fit chromosome aberration yield points in relation to $\mathrm{Pu}-239$ body burden. Figure 3 demonstrates the 
Fig. 2 Stable complex chromosomal aberration involving $2,7,11,17,22$ chromosomes
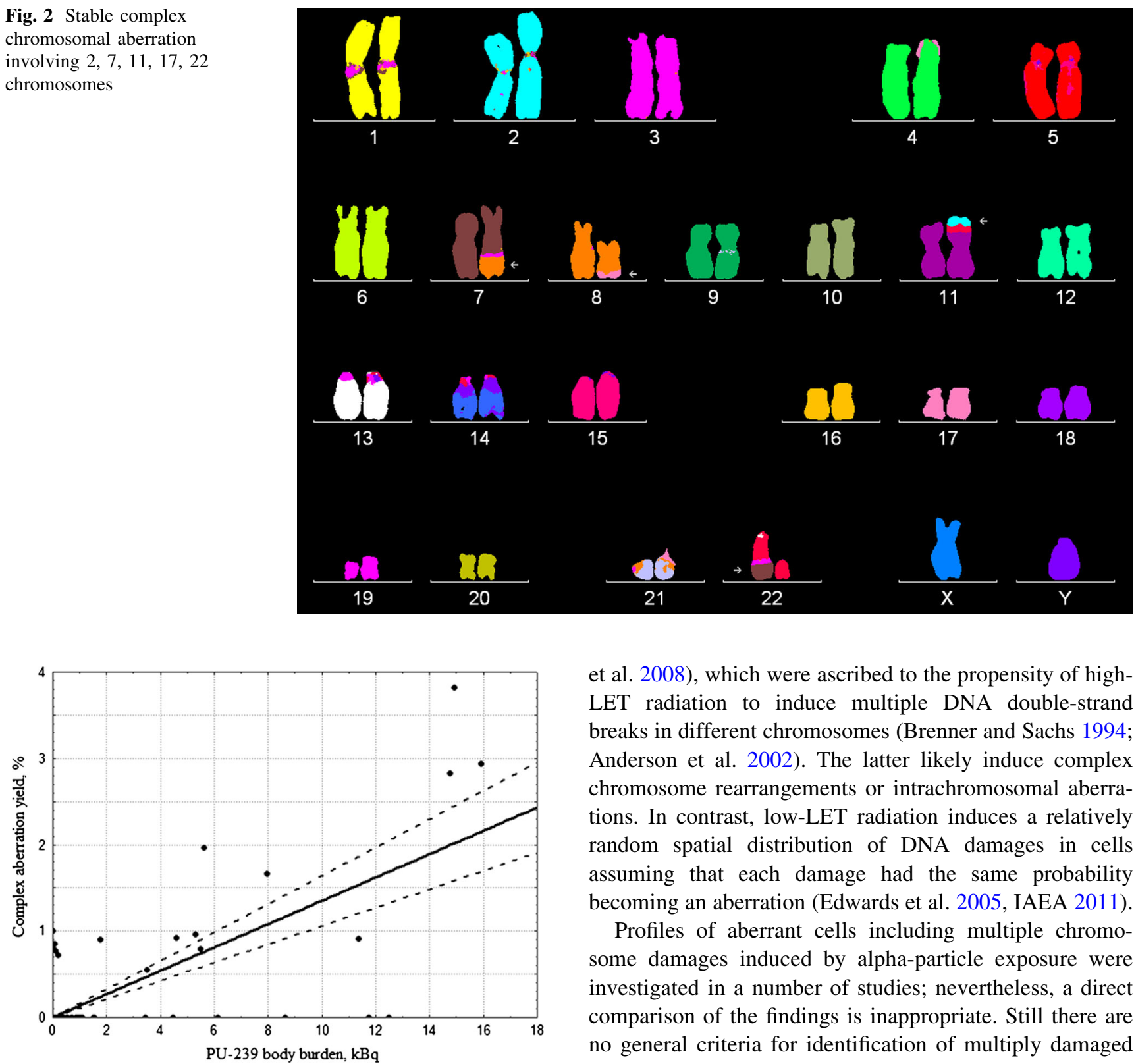

Fig. 3 Complex chromosome aberration yields in relation to plutonium-239 body burden. The stippled lines represent $95 \%$ confidence limits

linear relationship (including $95 \%$ confidence limits) between complexes and the Pu-239 body burden.

\section{Discussion}

In vitro studies revealed that high-LET radiation induces clustered DNA damages and complex chromosome aberrations (Anderson et al. 2000, 2003, 2005, 2006; Moquet et al. 2001; Barquinero et al. 2004; Hada et al. 2007; Janet et al. 2008), which were ascribed to the propensity of highLET radiation to induce multiple DNA double-strand breaks in different chromosomes (Brenner and Sachs 1994; Anderson et al. 2002). The latter likely induce complex chromosome rearrangements or intrachromosomal aberrations. In contrast, low-LET radiation induces a relatively random spatial distribution of DNA damages in cells assuming that each damage had the same probability becoming an aberration (Edwards et al. 2005, IAEA 2011).

Profiles of aberrant cells including multiple chromosome damages induced by alpha-particle exposure were investigated in a number of studies; nevertheless, a direct comparison of the findings is inappropriate. Still there are no general criteria for identification of multiply damaged cells; no exact definition has been suggested for cells containing this type of damages. A wide range of aberrant cells with a considerable number of chromosome aberrations are defined as cells with multiple chromosome damages; these are cells containing 5 and more chromosome exchange aberrations (Awa and Neel 1986), 3 and more dicentrics or dicentric equivalents (Rozgaj et al. 2002), 5 chromosome aberrations including at least 1 exchange (Lazutka 1996), more than 1 dicentric or centric ring (Lloyd et al. 1988), 3 and more breaks in 2 or 3 chromosomes (Anderson et al. 2000, 2003, 2005). Moreover, different studies used different criteria for aberration scoring and different chromosome staining techniques causing inconsistent results. For instance, the analysis of Pu-239induced chromosome aberrations by the simple FISH-assay 
Anderson et al. (2000) found that $45-56 \%$ of rearrangements were of a complex type, while mFISH investigation of similarly treated cells revealed an increased complex chromosomal rearrangement level of up to $83 \%$ (Anderson et al. 2002). The analysis of peripheral blood lymphocyte irradiated with americium-241 within a 0-1 Gy dose range by three chromosome FISH revealed an aberration profile containing $34 \%$ of complexes (Barquinero et al. 2004). Using a similar 3 color FISH setup, Moquet et al. (2001) reported that the frequency of complexes in lymphocytes was $25 \%$ after irradiation with $\mathrm{Pu}-239$ alpha-particles. Another simple FISH study showed the increased complex chromosomal rearrangement yield from $56 \%$ (following irradiation with bismuth-213 at dose $10 \mathrm{mGy}$ ) to $89 \%$ (bismuth-213 exposure at dose $500 \mathrm{mGy}$ ) (Tawn et al. 2007).

In all, we consider mFISH (Speicher et al. 1996) to be the most appropriate technique for identification of complexes. It enables karyotyping of all chromosomes within a single metaphase plate avoiding the need for a subsequent conversion to a whole genome equivalent aberration frequency and, thus, decreasing uncertainties of the approach. Staining of each chromosome pair with a specific color code allows to detect exchange aberrations of any type even in a case when a morphologically normal homologous chromosome is formed due to repair processes or when there is small exchange between chromosomes. Still, intrachromosomal exchanges will go unnoticed. Moreover, mFISH is eminently effective in case of chronic and mixed radiation exposure, since it reveals numerous types of chromosome aberrations in one experiment.

Stable complex chromosome aberrations may be used not only as biomarkers of high-LET radiation exposure (Hande et al. 2005), but may also act as a predictor of tumorigenesis in humans (Pejovic et al. 1992; Johansson et al. 1995; Gorunova et al. 1998; Mandahl 1996, Mitelman Database http://cgap.nci.nih.gov/Chromosomes/Mitelman). Complexes evidence high lymphocyte damage levels. While the damage of a differentiated lymphocyte may not pose a direct hazard to health, the possibility remains that similar damage to a stem or poorly differentiated cell may induce genomic instability and cancer formation, especially when the damage is not lethal. Even stable complexes may cause gene fusions leading to formation of aberrant transcripts or activation of oncoproteins which can alter cell proliferation and abrogate cell death pathways thereby driving, e.g., leukemic transformation (e.g., Aseeva et al. 2009). Epidemiological studies have previously reported increased risks of lung and liver cancer incidence in Mayak PA workers who incorporated plutonium-239 (Labutina et al. 2013), as well as a significant association of lung, liver and bone cancer mortality with the incorporated radionuclide in this cohort (Sokolnikov et al. 2008, Gilbert et al. 2013). All participants of the present study were not diagnosed with cancer at the time of blood sampling. However, the majority of cells $(91 \%)$ displaying complex chromosomal rearrangements in Mayak PA workers with more than $1.48 \mathrm{kBq} \mathrm{Pu}-239$ body burden were capable to undergo cell divisions. It can thus not be excluded that such cells in vivo may undergo transformation leading to tumorous malignances.

\section{Conclusion}

multi-color fluorescence in situ hybridization analysis of an aged population of Mayak workers revealed significantly increased translocation and complex chromosomal rearrangement yields in Mayak PA workers exposed to mixed radiation (external gamma-rays and internal alpha-particles). The translocation yield was shown to be a biological marker for the external gamma-ray exposure, while complexes may be an indicator of internal alpha-radiation exposure even decades after Pu-239 incorporation.

\section{References}

Anderson RM, Marsden SJ, Wright EG, Kadhim MA, Goodhead DT, Griffin CS (2000) Complex chromosome aberrations in peripheral blood lymphocytes as a potential biomarker of exposure to high-LET alpha-particles. Int J Radiat Biol 76:31-42

Anderson RM, Stevens DL, Goodhead DT (2002) M-FISH analysis shows that complex chromosome aberrations induced by alphaparticle tracks are cumulative products of localized rearrangements. Proc Natl Acad Sci USA 99:12167-12172

Anderson RM, Marsden SJ, Paice SJ, Bristow AE, Kadhim MA, Griffin CS, Goodhead DT (2003) Transmissible and nontransmissible complex chromosome aberrations characterized by three-color and mFISH define a biomarker of exposure to high-LET alpha particles. Radiat Res 159:40-48

Anderson RM, Tsepenko VV, Gasteeva GN, Molokanov AA, Sevan'kaev AV, Goodhead DT (2005) mFISH analysis reveals complexity of chromosome aberrations in individuals occupationally exposed to internal plutonium: a pilot study to assess the relevance of complex aberrations as biomarkers of exposure to high-LET $\alpha$-particles. Radiat Res 163:26-35

Anderson RM, Papworth DG, Stevens DL, Sumption ND, Goodhead DT (2006) Increased complexity of radiation-induced chromosome aberrations consistent with a mechanism of sequential formation. Cytogenet Genome Res 112:35-44

Aseeva EA, Snigiryova GP, Neverova AL, Novitskaya NN, Hasins ED, Domracheva EV (2009) Cells with multiple chromosomal aberrations in individuals exposed to different radiation types and their potential biological effects. Radiats Biol Radioecol 49(5):552-562

Awa AA, Neel JV (1986) Cytogenetic "Rogue" cells: what is their frequency, origin, and evolutionary significance? Natl Acad Sci 83:1021-1025

Barquinero F, Stephan G, Schmid E (2004) Effect of americium-241 $\alpha$-particles on the dose response of chromosome aberrations in human lymphocytes analysed by fluorescence in situ hybridization. Int J Radiat Biol 80:155-164 
Bauchinger M, Schmid E, Braselmann H (2001) Time-course of translocation and dicentric frequencies in a radiation accident case. Int J Radiat Biol 77:553-557

Boei JJ, Vermeulen S, Mullenders LH, Natarajan AT (2001) Impact of radiation quality on spectrum of induced chromosome exchange aberrations. Int J Radiat Biol 77:847-857

Borovikov V (2003) STATISTICA. The art of computer analysis of data for experts. $\mathrm{SPb}$, Piter

Brandom WF, Archer PG, Bloom AD, Archer VE, Bistline RW, Saccomanno G (1979) Chromosome changes in somatic cells of workers with internal deposition of plutonium, Biological implications of radionuclides released from nuclear industries II. IAEA, Vienna, pp 195-210

Brandom WF, McGavran L, Bistline RW, Bloom AD (1990) Sister chromatid exchanges and chromosome aberration frequencies in plutonium workers. Int J Radiat Biol 58(1):195-207

Brenner DJ, Sachs RK (1994) Chromosomal "fingerprints" of prior exposure to densely ionizing radiation. Radiat Res 140:134-142

Curwen GB, Tawn EJ, Cadwell KK, Guyatt L, Thompson J, Hill MA (2012) $\mathrm{mFISH}$ analysis of chromosome aberrations induced in vitro by $\alpha$-particle radiation: examination of dose-response relationships. Radiat Res 178:414-424

de Lemos Pinto MMP, Santos NFG, Amaral A (2010) Current status of biodosimetry based on standard cytogenetic methods. Radiat Environ Biophys 49:567-581

Dolphin GW (1971) The biological problems in the radiological protection of the workers exposed to ${ }^{239} \mathrm{Pu}$. Health Phys 20:549-557

Draper N, Smith H (1986) Applied regression analysis. Finance and Statistics, Moscow, p 366 [russian]

Edwards A, Lindholm C, Darroudi F, Stephan G, Romm H, Barquinero J, Barrios L, Caballin MR, Roy L, Whitehouse CA, Tawn EJ, Moquet J, Lloyd DC, Voisin P (2005) Review of translocations detected by FISH for retrospective biological dosimetry application. Radiat Prot Dosim 113:396-402

Edwards AA, Szłuinska M, Lloyd DC (2007) Reconstruction of doses from ionizing radiation using fluorescence in situ hybridization techniques. Br J Radiol 80:63-67

George K, Wu H, Willingham V, Furusawa Y, Kawata T, Cucinotta FA (2001) High- and low-LET induced chromosome damage in human lymphocytes: a time course of aberrations in metaphase and interphase. Int J Radiat Biol 77:175-183

Gilbert ES, Sokolnikov ME, Preston DL, Schonfeld SJ, Schadilov AE, Vasilenko EK, Koshurnikova NA (2013) Lung cancer risks from plutonium: an updated analysis of data from the Mayak worker cohort. Radiat Res 179:332-342

Gorunova L, Höglund M, Andren-Sandberg A, Dawiskiba S, Jin Y, Mitelman F, Johansson B (1998) Cytogenetic analysis of pancreatic carcinomas: intratumor heterogeneity and nonrandom pattern of chromosome aberrations. Genes Chromosomes Cancer 23:81-99

Hada M, Cucinotta FA, Gonda SR, Wu H (2007) mBAND analysis of chromosomal aberrations in human epithelial cells exposed to Low- and High-LET radiation. Radiat Res 168:98-105

Hande MP, Azizova TV, Burak LE, Khokhryakov VF, Geard CR, Brenner DJ (2005) Complex chromosome aberrations persist in individuals many years after occupational exposure to densely ionizing radiation: an mFISH study. Genes Chromosomes Cancer 44:1-9

Hempelmann LH, Langham WH, Richmond CR, Voelz GL (1973) Manhattan project plutonium workers: a twenty-seven year follow-up study of selected cases. Health Phys 25:461-479

International Atomic Energy Agency (2001) Cytogenetic analysis for radiation dose assessment. A manual. Technical Report Series No 405 (IAEA, Vienna)

International Atomic Energy Agency (2011) Cytogenetic dosimetry: applications in preparedness for and response to radiation emergencies. IAEA, Vienna
Iwasaki T, Takashima Y, Suzuki T, Yoshida MA, Hayata I (2011) The dose response of chromosome aberrations in human lymphocytes induced in vitro by very low-dose $\gamma$ rays. Radiat Res 175:208-213

Janet E, Whitehouse CA, Holdsworth D, Ruyck KD, Vandenblock K, Thierence H (2008) mBand analysis of chromosome aberrations in lymphocytes exposed in vitro to $\alpha$-particles and $\gamma$-rays. Int $\mathbf{J}$ Radiat Biol 84:447-453

Johansson M, Jin Y, Mandahl N, Hambraeus G, Johansson L, Mitelman F, Heim S (1995) Cytogenetic analysis of short-term cultured squamous cell carcinomas of the lung. Cancer Genet Cytogenet 81:46-55

Khokhryakov V, Suslova K, Aladova E, Vasilenko E, Miller SC, Slaughter DM, Krahenbuhl MP (2000) Development of an improved dosimetry system for the workers at the Mayak production association. Health Phys 79:72-76

Khokhryakov VV, Khokhryakov VF, Suslova KG, Vostrotin VV, Vvedensky VE, Sokolova AB, Krahenbuhl MP, Birchall A, Miller SC, Schadilov AE, Ephimov AV (2013) The Mayak production association worker internal dosimetry system 2008 (MWDS-2008). Health Phys 104:366-378

Labutina EV, Kuznetsova IS, Hunter N, Harrison J, Koshurnikova NA (2013) Radiation risk of malignant neoplasms in organs of main deposition for plutonium in the cohort of Mayak workers with regard to histological types. Health Phys 105:165-176

Lazutka JR (1996) Chromosome aberrations and rogue cells in lymphocytes of Chernobyl cleanup workers. Mutat Res 350:315-329

Livingston GK, Falk RB, Schmid E (2006) Effect of occupational radiation exposures on chromosome aberration rates in former plutonium workers. Radiat Res 166:89-97

Lloyd DC, Edwards AA, Leonard A, Deknudt G, Natarajan A, Obe G, Palitti F, Tanzarella C, Tawn EJ (1988) Frequencies of chromosomal aberrations induced in human blood lymphocytes by low doses of X-rays. Int J Radiat Biol 53:49-55

Mandahl N (1996) Cytogenetics and molecular genetics of bone and soft tissue tumors. Adv Cancer Res 69:63-99

Mitelman Database of Chromosome Aberrations in Cancer http:// cgap.nci.nih.gov/Chromosomes/Mitelman

Moquet JE, Fernandez JL, Edwards AA, Lloyd DC (2001) Lymphocyte chromosomal aberrations and their complexity induced in vitro by plutonium-239 alpha-particles and detected by FISH. Cell Mol Biol (Noisy-le-grand) 47:549-556

Okladnikova ND, Scott BR, Tokarskaya ZB, Zhuntova GV, Khokhryakov VF, Syrchikov VA, Grigoryeva ES (2005) Chromosomal aberrations in lymphocytes of peripheral blood among Mayak facility workers who inhaled insoluble forms of ${ }^{239} \mathrm{Pu}$. Radiat Prot Dosim 113:3-13

Okladnikova ND, Osovets SV, Kudryavtseva TI (2009) Plutonium239 and chromosomal aberrations in human peripheral blood lymphocytes. Radiats Biol Radioecol 49:407-411

Pejovic T, Heim S, Mandahl N, Baldetorp B, Elmfors B, Floderus UM, Furgyik S, Helm G, Himmelmann A, Willen H (1992) Chromosome aberrations in 35 primary ovarian carcinomas. Genes Chromosomes Cancer 4:58-68

Pernot E, Hall J, Baatout S, Benotmane MA, Blanchardon E, Bouffler S, El Saghire H, Gomolka M, Guertler A, Harms-Ringdahl M, Jeggo P, Kreuzer M, Laurier D, Lindholm C, Mkacher R, Quintens R, Rothkamm K, Sabatier L, Tapio S, de Vathairem V, Cardis E (2012) Ionizing radiation biomarkers for potential use in epidemiological studies. Mutat Res 751:258-286

Popova NA, Nazarenko LP, Nazarenko SA (2004) Multiaberrant cells after internal exposure to densely ionizing radiation sources. Genetics 40(12):1709-1713 (in Russian)

Rozgaj R, Kasuba V, Simic D (2002) The frequency of dicentrics and acentrics and the incidence of rogue cells in radiation workers. Mutagenesis 17:135-139 
Schofield GB (1980) Biological control in a plutonium production facility. Br J Radiol 53:398-409

Sigurdson A, Ha M, Hauptmann M, Bhatti P, Sram RJ, Beskid O, Tawn EJ, Whitehouse CA, Lindholm C, Nakano M et al (2008) International study of factors affecting human chromosome translocations. Mutat Res 652:112-121

Sokolnikov ME, Gilbert ES, Preston DL, Ron E, Shilnikova NS, Khokhryakov VV, Vasilenko EK, Koshurnikova NA (2008) Lung, liver and bone cancer mortality in Mayak workers. Int $\mathbf{J}$ Cancer 123:905-911

Speicher MR, Gwyn Ballard S, Ward DC (1996) Karyotyping human chromosomes by combinatorial multi-fluor FISH. Nat Genet 12(4):368-375

Tawn EJ, Whitehouse CA (2005) Chromosome intra- and interchanges determined by G-banding in radiation workers with in vivo exposure to plutonium. J Radiol Prot 25:83-88

Tawn EJ, Hall JW, Schofield GB (1985) Chromosome studies in plutonium workers. Int J Radiat Biol 47:599-610

Tawn EJ, Whitehouse CA, Ruyck KD, Hodgson L, Vandenbulcke K, Thierens $H$ (2007) The characterization and transmissibility of chromosome aberrations induced in peripheral blood lymphocytes by in vitro $\alpha$-particle radiation. Radiat Res 168:666-674

Testard I, Dutrilaux B, Sabatier L (1997) Chromosomal aberrations induced in human lymphocytes by high-LET irradiation. Int $\mathbf{J}$ Radiat Biol 72:423-433

Tucker JD (2008) Low-dose ionizing radiation and chromosome translocations: a review of the major considerations for human biological dosimetry. Mutat Res 659:211-220
UNSCEAR (2000) report to the General Assembly. Exposures and effects of the Chernobyl accident. Int J Radiat Med Special ISSUE 2-4(6-8):3-109

Vandenbulcke K, De Vos F, Offner F, Philippé J, Apostolidis C, Molinet R, Nikula TK, Bacher K, de Gelder V, Vral A, Lahorte C, Thierens H, Dierckx RA, Slegers G (2003) In vitro evaluation of 213Bi-rituximab versus external gamma irradiation for the treatment of B-CLL patients: relative biological efficacy with respect to apoptosis induction and chromosomal damage. Eur $\mathbf{J}$ Nucl Med Mol Imaging 30(10):1357-1364

Vasilenko EK, Khokhryakov VF, Miller SC, Fix JJ, Eckerman K, Choe DO, Gorelov M, Khokhryakov VV, Knyasev V, Krahenbuhl MP, Scherpelz RI, Smetanin M, Suslova K, Vostrotin V (2007) Mayak worker dosimetry study: an overview. Health Phys 93:190-206

Voelz GL, Grier RS, Hempelmann LH (1985) A 37-year medical follow-up of Manhattan project plutonium workers. Health Phys 48:249-259

Whitehouse CA, Tawn EJ (2001) No evidence for chromosomal instability in radiation workers with in vivo exposure to plutonium. Radiat Res 156:467-475

Whitehouse CA, Tawn EJ, Riddell AE (1998) Chromosome aberrations in radiation workers with internal deposit of plutonium. Radiat Res 150:459-468 